\title{
The nature of kimberlite melts, rocks and magmas
}

\author{
R. S. J. Sparks, R.A. Brooker, R.J. Brown, M. Field, J. Kavanagh, R. Ogilvie-Harris, J.C. \\ Schumacher, M.J. Walter, and J. White \\ Department of Earth Sciences, University of Bristol, Bristol, BS8 1RJ, UK
}

\begin{abstract}
The primary compositions of kimberlite melts and magmas are elusive due to contamination by xenolithic material, strong alteration, notably by serpentisation, and, in the case of pyroclastic rocks, chemical differentiation due to sorting by eruptive processes. We show that textures and mineralogical attributes of kimberlite dykes and sills indicate that igneous calcite is replaced by serpentine, producing an increase in $\mathrm{Si}$ and $\mathrm{Mg}$ and decrease in $\mathrm{Ca}$ and $\mathrm{CO}_{2}$. Reconstructed kimberlite magma compositions, taking into account alteration, are shifted towards silica-poor compositions transitional to carbonatite, indicating overestimation of $\mathrm{Si}$ and $\mathrm{Mg}$ contents in previous assessments. Experimental data at near-surface pressures with excess $\mathrm{CO}_{2}$ and $\mathrm{H}_{2} \mathrm{O}$ show that $\mathrm{Si}$ and $\mathrm{Mg}$-rich compositions have high liquidus temperatures inconsistent with estimated kimberlite magma temperatures $\left(1030-1170^{\circ} \mathrm{C}\right)$. Experiments with more carbonate-rich and silica-poor reconstructed compositions have much lower liquidus temperatures, as long as water is present. We suggest that initial kimberlite melts from the asthenosphere are hydrous and carbonate-rich; compositions that are consistent with other suggestions about the nature of deep asthenospheric melts. They may have their silica content increased by orthopyroxene and olivine assimilation, exsolve some $\mathrm{CO}_{2}$ during ascent and carry a significant amount of water. Olivine crystallization, as a consequence of decompression, degassing and cooling during ascent decreases the silica content of the melt phase. The rapid loss of this water as magmas approach the surface can cause extensive crystallization and explosive volcanism. Subtle changes in magma composition across the carbonate-silicate transition can have profound effects on the liquidus temperature, which is exaggerated during near surface degassing. For the same initial volatile content, small changes in silica content can determine the fate of a magma, between non-explosive intrusions of volatile rich dykes and sills or a catastrophic explosive eruption as magma freezes and there is runaway degassing. Many kimberlites, including some that have previously been interpreted as hypabyssal, have a pyroclastic origin. Significant changes in mineral proportions and chemical composition can arise by fluidisation in volcanic vents with concentration of olivine and selective removal of groundmass (melt) components. Finally almost all kimberlites have their bulk silica and magnesia contents increased by post-emplacement serpentinization.
\end{abstract}

\section{Introduction}

Kimberlite magmas are commonly contaminated with crustal and mantle xenoliths and xenocrysts, and are typically strongly altered, notably by serpentisation of olivine. These characteristics make it difficult to reconstruct the compositions of the magmas. Strategies include sampling fine-grained autholiths (Ferguson et al., 1975), sampling the margins of aphanitic kimberlite dykes and sills (Price et al., 2000; Le Roux et al., 2003), and making reconstructions based on the geochemistry of suites of associated kimberlites (Harris et al.,2004; Becker and Le Roux, 2006). Such studies yield estimated ranges of the main components: $\mathrm{SiO}_{2}$ (25 to $35 \% \mathrm{wt} \%$ ), $\mathrm{MgO}$ (25 to $35 \mathrm{wt} \%$ ), $\mathrm{CaO}$ (12 to $20 \mathrm{wt} \%$ ) and $\mathrm{CO}_{2}$ (5 to $12 \mathrm{wt} \%$ ). In contrast the Igwisi Hills lava and sills at Wesselton and Benfontein are rich in primary carbonate. Melting experiments on carbonated mantle (Dalton et al., 1998) define a trend between carbonatites and the silica-rich kimberlite field (Fig. 1).

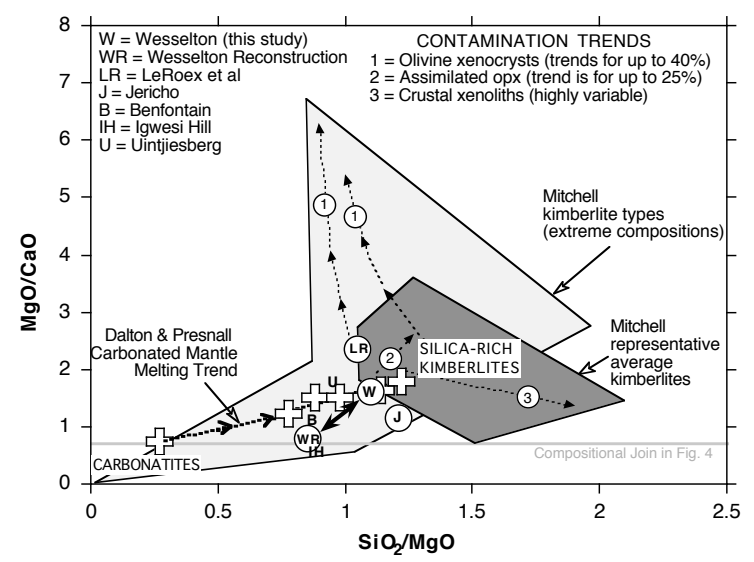

Figure 1. Kimberlite compositions expressed as wt\% ratios of $\mathrm{SiO}_{2}, \mathrm{MgO}$ and $\mathrm{CaO}$. fields for kimberlites (shaded) are from Mitchell (1986) and possible contamination trends are shown. Recent estimates of primary kimberlite composition ( $L R, J$ and $u$ ) all plot at the low ratio corner of this field towards the carbonatite field. A reconstructed Wesselton composition (WR) is close to calcite-kimberlites (B) and (IH). Crosses show experimental melts from a simplified carbonated mantle system at $6.0 \mathrm{GPa}$ (Dalton and Presnell, 1998), which start near the carbonatite corner at $1380^{\circ} \mathrm{C}$ and move towards the kimberlite field between 1405 and $1430^{\circ} \mathrm{C}$.

Silica-rich kimberlites are enigmatic in that experimental studies over a wide range of deep mantle pressures (3-10 GPa) in the $\mathrm{CaO}-\mathrm{MgO}-\mathrm{SiO}_{2}$ - 
$\mathrm{CO}_{2}$ and peridotite- $\mathrm{CO}_{2}$ systems suggest that such 'transitional' melt compositions form in a narrow temperature pressure-dependent window. Melts formed near the mantle solidus are carbonatitic and only develop silica-rich kimberlite affinities at higher temperatures, for example at $1455-1505^{\circ} \mathrm{C}$ for $6 \mathrm{GPa}$ even though the degree of partial melting is still very small ( $\sim 1 \%)$. High temperatures required for silica-rich kimberlite are inconsistent with temperatures of $1400^{\circ} \mathrm{C}$ at the base of the continental lithosphere inferred from mantle nodules (Priestley et al., 2006).

Other constraints on kimberlite magma properties include estimates of near surface temperatures of 1030$1170^{\circ} \mathrm{C}$ (Fedortchouk \& Canil, 2004), the lack of orthopyroxene xenocrysts in macrocyrstic varieties, and the explosive nature of the volcanism.

\section{Effects of Serpentinisation}

Textures and mineral assemblages from kimberlites indicate that serpentisation severely effects their bulk compositions. Sills associated with the Wesselton pipe, Kimberley, South Africa are intruded into Lower Karoo Dwyka shales in a zone of a few metres thick below an Upper Karoo dolerite sill (Shee et al., 1991). Aphanitic varieties containing groundmass olivine are candidates as kimberlite melt compositions (W in Fig. 1). Mineral assemblages consist of variable proportions of serpentine, phlogopite, calcite, spinel (chrome spinel and FeTi-rich spinel), perovskite, apatite and clay minerals. The calcite is mostly of igneous origin as demonstrated by interlocking textures with other euhedral minerals and high $\mathrm{SrO}$ content (0.4 -1.8 wt\%). Olivine crystals are pseudomorphed by platy serpentine, surrounded by a zone of amorphous serpentine that replaces surrounding calcite, apatite and pholgopite (Fig. 2). Titanomagnetite and perovskite are unaffected. In olivine-rich macrocrystic dykes olivine macrocrysts also display two rims of serpentine around a pseudomorphed core. The inner rim is amorphous and lacks any inclusions while the outer rim enclose unreacted minerals, such as perovskite and spinel and displays replacive textures with calcite.

Serpentinisation involves large volume changes. When olivine is pseudomorphed $\mathrm{Mg}$ and $\mathrm{Si}$ are released into the fluid phase. The volume increase was estimated at $184 \%$ by Stripp et al. (2006). To form serpentine around the olivine in the Wesselton rocks from the $\mathrm{Mg}$ and $\mathrm{Si}$ released by this reaction requires additional $\mathrm{Si}$. The extra Si could be from the alteration of pholgopite or introduced by fluid that has equilibrated with surrounding shales. We measured the modal proportions of 24 olivine microphenocrysts pseudomorphs and their associated amorphous serpentine rims in an aphanitic sill at $68 \%$ and $32 \%$ respectively, a result consistent with the expected volume increase of the reaction. The main effect of alteration is to increase in relative terms the bulk Si and $\mathrm{Mg}$ content and decrease the $\mathrm{Ca}$ and $\mathrm{CO}_{2}$ content of the rock. Serpentisation can involve open system alteration with loss of $\mathrm{Mg}$ relative to $\mathrm{Si}$ in escaping fluids.
Using modal data from an aphanitic Wesselton sill, we have calculated the rocks original (prealteration) composition using representative mineral densities to convert from volume to weight percent and assuming that the rim serpentine was originally calcite. The reconstructed compositon (WR in Fig. 1) has $17.4 \% \mathrm{SiO}_{2}$ and $25.6 \% \mathrm{CaO}$ compared to $26 \%$ and $14.7 \%$ respectively in the bulk rock. After taking serpentisation into account, we suggest that Group 1 kimberlite melts in the shallow crust trend towards carbonatite with have low $\mathrm{SiO}_{2}(\sim 15-25 \%)$, $\mathrm{MgO}$ contents in the range 10 to $25 \%$ and $\mathrm{CO}_{2}$ contents in the range 10 to $20 \%$.

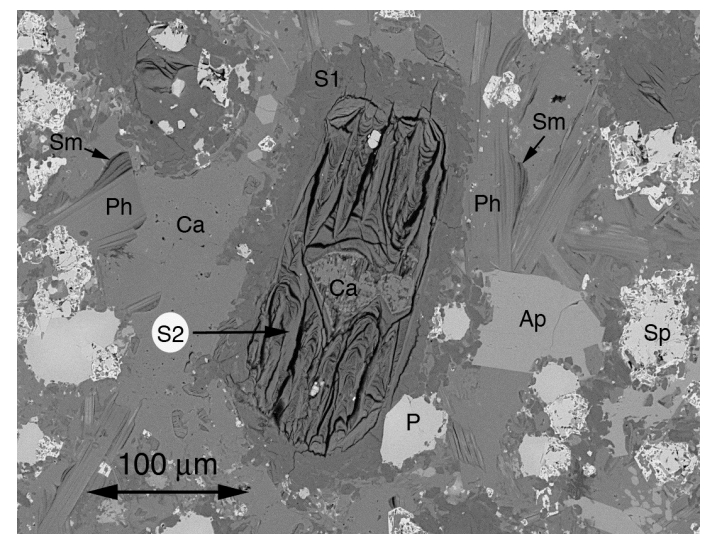

Figure 2. Back-scattered SEM image shows serpentine pseudomorphs after olivine (S2) in aphanitic kimberlite sill, Wesselton. The olivine pseudomorph is surrounded by a clear zone of serpentine (S1) replacing high $\mathrm{Sr}$ and $\mathrm{Ba}$ igneous calcite (Ca), apatite (Ap) and phologopite $(\mathrm{Ph})$. Other groundmass phases include perovskite $(P)$, spinel $(\mathrm{Sp})$, and smectite after pholgopite (Sm).

\section{The role of volatiles}

$\mathrm{CO}_{2}$ is thought to be a major component in kimberlite magma, but models of $\mathrm{CO}_{2}$ solubility (Brey \& Ryabchikov, 1994) suggest a silica-rich kimberlite melt is unlikely to carry more than $3 \mathrm{wt} \%$ $\mathrm{CO}_{2}$ in solution past an ascent depth of $3 \mathrm{~km}$. Experiments on silici-kimberlites support this low value, and although we observe the addition of water to the system increases the $\mathrm{CO}_{2}$ solubility, it is still not close to the inferred values for $\mathrm{CO}_{2}$ (or water) in kimberlites emplaced at even shallower depths. Up to $12 \mathrm{wt} \% \mathrm{CO}_{2}$ is observed in aphanitic samples and original contents may have been higher due to serpentinization. This discrepancy can be resolved if kimberlites were originally $\mathrm{SiO}_{2}$-poor (silicate carbonatites) with a much higher capacity to carry $\mathrm{CO}_{2}$, as a consequence. The common presence of phlogopite as phenocrysts and in the groundmass also suggests the melts are hydrous. In mantle melting, water reduces the solidus, increases the degree of partial melting and allows kimberlite melts to be generated at lower temperatures. 


\section{Experiments and thermodynamics}

We carried out experiments at $0.1 \mathrm{GPa}$ pressure $(\sim 3$ km) with excess $\mathrm{CO}_{2}$, excess $\mathrm{H}_{2} \mathrm{O}$, and $\mathrm{CO}_{2}-\mathrm{H}_{2} \mathrm{O}$ mixtures using the relatively silica-rich primary kimberlite composition proposed by Le Roex et al. (2004). At $1250^{\circ} \mathrm{C}$, the experiments have $<30 \%$ melt and are dominated by $\mathrm{Ca}$-rich $(\sim 2-4 \% \mathrm{CaO})$ olivine, with minor spinel and monticellite. High Ca-content olivines are not observed in kimberlites, but the results are consistent with the closure of the olivinemonticellite solvus at high temperatures. These results are difficult to reconcile with intrusion of silica-rich kimberlite melts at temperatures $<1170^{\circ} \mathrm{C}$ and at depths of $<3 \mathrm{~km}$. In contrast, similar experiments on a $\mathrm{SiO}_{2}-$ poor reconstructed Wesselton composition have up to $60 \%$ melt remaining at $1200^{\circ} \mathrm{C}$ as long as significant amounts of water are present. The principle of a dramatic change in the melt fraction and much lower solidus temperatures for a relatively small change in silica content has been illustrated for the simplified CMS $+\mathrm{CO}_{2}+\mathrm{H}_{2} \mathrm{O}$ system by Otto \& Wyllie (1993) at $0.2 \mathrm{GPa}$. The 'transition' appears to be around 25-30 $\mathrm{wt} \% \mathrm{SiO}_{2}$ and the presence of water allows for residual carbonate-rich melts down to $<700^{\circ} \mathrm{C}$.

Adiabatic cooling of kimberlite melts ascending from $200 \mathrm{~km}$ depth accounts for $200-250^{\circ} \mathrm{C}$ with even larger coolings when volatile exsolution is considered. These calculations, together with the experimental results, suggest that published estimates of kimberlite melts are too rich in $\mathrm{SiO}_{2}$ and $\mathrm{MgO}$ to be viable melts in the shallow crust. We propose that the melt compositions are along the trend towards carbonatites (Fig. 1) with $<<25 \% \mathrm{SiO}_{2}$ and likely $<<25 \% \mathrm{MgO}$ at temperatures $<1150^{\circ} \mathrm{C}$.

\section{Group 1 Kimberlites as deep asthenospheric melts}

The similarity and character of the trace element patterns of Group 1 kimberlites is consistent with extraction of small degree partial melts from the deep upper mantle asthenosphere via porous flow processes. Geophysical and experimental data beneath mid-ocean ridges suggest that the upper mantle above the transition zone contains small amounts of partial melt to depths of at least $300 \mathrm{~km}$. Gasgupta and Hirschmann (2006) proposed that these melts are carbonatite in composition, but their experimental study did not include water as a component.

Group 1 kimberlites can be explained by the generation of water-rich, carbonate-rich melts in the asthenosphere, which assimilate silicate mantle components during ascent. Such melts can ascend to the surface with assimilation of mantle silicates en route due to reactions with entrained mantle crystals and superheat effects during decompression. Dissolution of orthopyoxene may also be accompanied by precipitation of olivine phenocrysts with the melts becoming more silica and magnesia rich as they ascend. In the shallow crust olivine crystallization cuased by cooling and degassing can drive residual melts back to low temperature carbonate and siklica- poor melts, which precipitate as the typical groundmass minerals of kimberlite. The resulting carbonate-rich wet kimberlite magmas can ascend and erupt as mobile, and very explosive magmas.

\section{References}

Becker, M. \& Le Roex, A.P. 2006. Geochemistry of South African on and off-craton Group I and Group II Kimberlites: petrogenesis and source evolution. J. Petrol. 47, 673-703.

Brey, G.P. \& Ryabchikov, I.D. 1994. Carbon dioxide in strongly undersaturated melts and origin of kimberlite magmas. N. Jb. Miner. Mh. H 10, 449-463.

Fedortchouk, Y. \& Canil, D. 2004. Intensive variables in kimberlite magmas, Lac de Gras, Canada and implications for diamond survival. J. Petrol. 45, 1725-1745.

Dalton, J.A., \& Presnell, D.C. 1998. The continuum of primary carbonatitic-kimberlite melt compositions in equilibrium with lherzolite: data from the system $\mathrm{CaO}$ MgO- $-\mathrm{Al}_{2} \mathrm{O}_{3}-\mathrm{SiO}_{2}-\mathrm{CO}_{2}$ at 6 GPa. J. Petrol. 39, 1953-1964.

Dasgupta, R. \& Hirschmann, M.M. 2006. Melting in the Earth's deep upper mantle caused by carbon dioxide. Nature 440, doi:10.1038.

Ferguson, J., Danchin, R.V. \& Nixon, P.H. 1975. Petrochemistry of kimberlite autoliths. Lesotho Kimberlites, 285-293.

Harris, M., le Roex, A., \& Class, C. 2004. Geochemistry of the Unitjiesberg kimberlite, South Africa: petrogenesis of an off-craton, group 1, kimberlite. Lithos 74, 149-165.

Le Roex, A.P., Bell, D.R. \& Davis, P. 2003. Petrogenesis of group 1 kimberlites from Kimberley, South Africa: evidence from bulk rock chemistry. J. Petrol. 44, 22612286.

Mitchell, R.H. 1986. Kimberlites: Mineralogy, Geochemistry and Petrology. Plenum Press, NY, p442.

Otto, J.W \& Wyllie, P.J. 1993. Relationships between silicate melts and carbonate-precipitating melts in $\mathrm{CaO}-$ $\mathrm{MgO}-\mathrm{SiO}_{2}-\mathrm{CO}_{2}-\mathrm{H}_{2} \mathrm{O}$ at 2 kbar. Mineral. Petrol. 48, 343365 .

Price, S.E., Russell, J.K. \& Koplova, M.G. 2000. Primitive magma from the Jericho Pipe, N.W.T., Canada: Constraints on primary kimberlite melt chemistry. J. Petrol. 41, 789-808.

Priestly, K., McKenzie, D. \& Debayle, E., 2006. The state of the upper mantle beneath southern Africa. Phys. Chem. Earths Interior, 416, 101-112.

Shee, S.R., Clement, C.R. \& Skinner, E.M.W. 1991. The petrology of the Wesselton kimberlite sills, Kimberley, Cape Province, South Africa. Proceedings $5^{\text {th }}$ International Kimberlite Conference, Brazil.

Stripp, G.R., Field, M., Schumacher, J. C., Sparks, R.S.J. \& Cressey, G. 2006. Post Emplacement Serpentinization and Related Hydrothermal Metamorphism in a Kimberlite from Venetia, South Africa. J. Metamorphic Geol. 24, 515-534. 
